\title{
触 New Disease Reports \\ Natural occurrence of Bhendi yellow vein mosaic virus on Litsea spp. in India
}

\author{
B. Roy, B. Chakraborty, A. Mitra, S. Sultana and A.R. Sherpa*
}

Department of Botany, West Bengal State University, Berunanpukuria, Malikapur, Barasat, 24 North Parganas, Kolkata, 700126, West Bengal, India

*E-mail: ang2001@gmail.com

Received: 07 Jan 2015. Published: 15 Feb 2015. Keywords: Geminivirus, natural host, India, detection, Begomovirus

Abelmoschus esculentus (Malvaceae) commonly called okra, lady's finger, bhendi or bindi is an important vegetable crop grown in West Bengal, India. The plant is susceptible to a most important and destructive Begomovirus: Bhendi yellow vein mosaic virus (BYVMV) that causes severe economic losses. BYVMV was first reported from Mumbai in India (Kulkarni, 1924). Okra infected with BYVMV has been reported in Asia in Bangladesh, India, Pakistan, Thailand, Sri Lanka and China (Kulkarni, 1924; Tsai et al., 2013). During summer season surveys in Barasat, West Bengal, India in 2013 and 2014, both Litsea apetala and L. sebifera (Lauraceae) exhibited typical symptoms of geminivirus infection, including leaf curling, deformation, leaf yellowing, vein clearing, mosaic and stunted growth (Fig. 1). Total DNA was isolated from diseased leaves using a modified CTAB procedure (Ghosh et al., 2009) and the extract tested for the presence of geminiviruses by PCR using a pair of degenerate geminivirus-specific primers (GEM-F: 5'-ATRRTHTGGATGGAYGARAACAT-3'; GEM-R 5'- AAATCCCCTNTATTTCAAARAT-3') amplifying approximately 760 bp of sequence partially overlapping the putative AV1, AC3 and AC2 genes (Fig. 2). The sequences from both $L$. sebifera and $L$. apetala share 93-99\% identity with the sequences of several BYVMV isolates, while they share $98 \%$ identity with each other at the nucleotide level. Both viral sequences from $L$. apetala and $L$. sebifera were submitted to the DDB. sequence database as Bhendi yellow vein mosaic virus, isolate Barasat (GenBank Accession No. LC010941) and Bhendi yellow vein mosaic virus, isolate Barasat7 (LC010947), respectively. To the best of our knowledge this is the first report of $L$. apetala and $L$. sebifera as natural and alternative

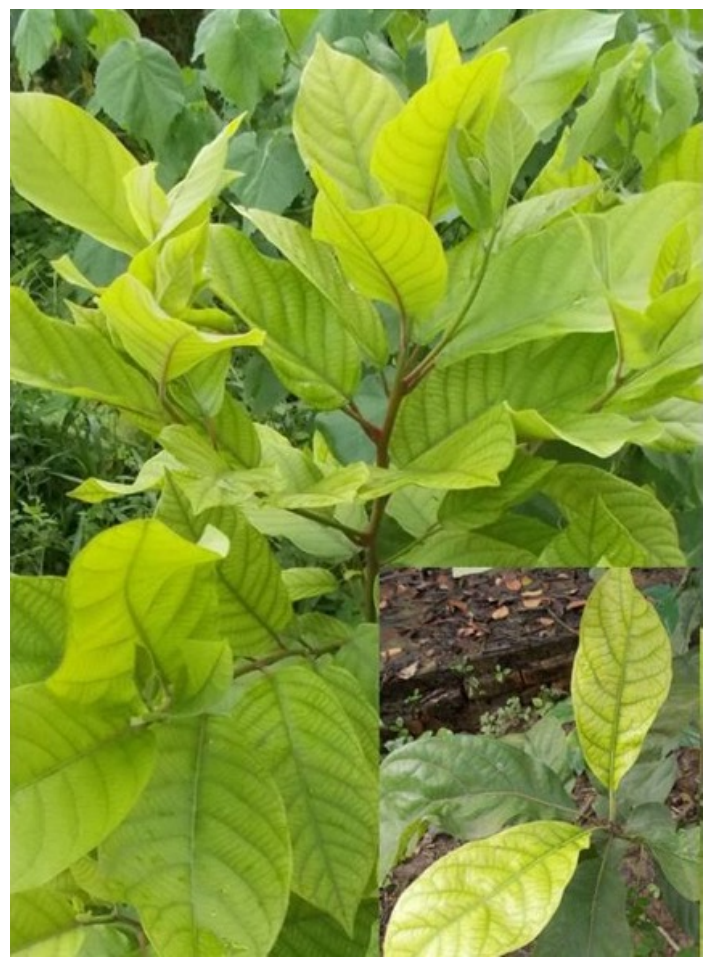

Figure 1 hosts of BYVMV in India. This result supports the notion that geminiviruses are important emerging and devastating viruses causing threats to crops (Varma \& Malathi, 2003). Therefore, there is a need for further detailed study on the diversity of BYVMV, viral disease management, and identification of alternative hosts that may act as virus reservoirs.

\section{Acknowledgements}

The authors would like to thank Prof. G.G. Maiti for his excellent expertise in the identification of the host plants.

\section{References}

Ghosh R, Paul S, Ghosh SK, Roy A, 2009. An improved method of DNA isolation suitable for PCR based detection of begomoviruses from jute and other mucilaginous plants. Journal of Virological Methods 159, 34-39.

Kulkarni GS, 1924. Mosaic and other related diseases of crops in the Bombay presidency. Poona Agricultural College Magazine 6, 12.

Tsai WS, Shih SL, Lee LM, Wang JT, Duangsong U, Kenyon L, 2013. First Report of Bhendi yellow vein mosaic virus associated with yellow vein mosaic of okra (Abelmoschus esculentus) in Thailand. Plant Disease 97, 291. http://dx.doi.org/10.1094/PDIS-09-12-0847-PDN

Varma A, Malathi VG, 2003. Emerging geminivirus problems: A serious threat to crop production. Annals of Applied Biology 142, 145-164.

To cite this report: Roy B, Chakraborty B, Mitra A, Sultana S, Sherpa AR, 2015. Natural occurrence of Bhendi yellow vein mosaic virus on Litsea spp. in India. New Disease Reports 31, 7. http://dx.doi.org/10.5197/j.2044-0588.2015.031.007 